\title{
老いの始まりの徴候の認知の性差・年齢差
}

\section{大城 冝武*}

\section{Sex and Age Differences in the Cognitions of "Getting Old"}

\section{Yoshitake OSHIRO*}

Eight hundred and two men and women of wide age range. responded to a questionnaire concerning signs of being old.

Main results were as follows.

1) Physical health resources were most frequently cited (59.0\%) as the signs of being old.

2) Significant sex differences were found in five out of the ten indices of being old. While women regarded the decline of psysical resource and being granted a pension, men tended to view the retirement as initial signs of being old.

3) Significant age differences were found in eight out of ten indices. The middle age group viewed the declined of physical resources, young group viewed the receiving of a pension, and the old group viewed the failure of their memory, respectively as the incipent signs of being old.

4) Multivariate analysis of the ten incipient signs of being old by means of Hayashi's quantification theory type III yielded four groups. They were named, "role transfer along the life cycle", "being given an old age title", "physical decline and pension", and "loss of active interest".

Key words : cognition, incipient signs of being old, sex differences, age differences,

Okinawa

認知, 老いの始まりの徵候, 性差, 年齢差, 沖縄

\section{I 緒言}

高齢期はどのような時期であろうか, 高齢期は どのように認知されているのだろうか.

Pitt (1977) は「老人とは, 年をとるとともに進 行する機能と作業の衰えである」と述べ，また， 「老化とは衰退の時期である」として老年で味わう
7 つ岥失を列挙している.すなわち, 地位, 収 入, 健康, 仲間, 自立, 居住設備, 生命, である. 守屋・長谷川（1979）は「老年期はいろいろな 面で衰退ならびに虽失が目立ってくる時期であ る. 老年期が一般に衰退期として特徵づけられる 所以である」と述べ, 井上 (1988) は, 長谷川・ 賀集（1977）によりつつ「老年期になると，人は

* 沖縄キリスト教短期大学・総合教育系

* General Education, Okinawa Christian Junior College 
多かれ少なかれ, あるいは遅かれ早かれ大きく4 つ失うものがある」とし，4 つの衰失について列 挙している.すなわち, (1)心身の健康の喪失, (2) 経済的基盤の賈失, (3)社会的つながりの岥失, (4) 生きる目的の喪失, である.ここで重要な事は, 4 つの喪失にみまわれることでなく,「生きる意味 の变失」感であり，「生きる意味の喪失」感こそま さに老年期を特徴づける事実である, と主張して いる。

田中ら（1981）は「老人問題は，おおまかに疾 病 (健康と疾病の問題), 孤独 (心理の問題), 貧 困（経済の問題）の 3 つであるといわれている」 と述べている，藍澤ら（1991）は「従来から指摘 されてきた健康, 経済, 人間関係の 3 つの要因が, 老年期の適応を左右する」としている.

新福 (1994) は，「一般的には，老いは人を悲し みや苦しみに陥れることが多いので，医学や医療 の進歩によって寿命が伸び，老人が多くなればな るほど，悲しみや悩みに陷るものが多くなること を予想しなければならない」と述べ，老年期にお ける知能の衰え, 人格面の変化, 社会的適応性の 変化, 生産性の低下を, 挙げている。

Ward (1977) は，老いる事への否定的なステレ オタイプを Goffman（1963）によりつつ，スティ グマ (Stigma) と呼び, それが自己侮荗感と強く 関連する，と主張している。

袖井（1975）は，包括的に老年期開始の理論的 検討を行っているが，発達論的アプローチによる 老年期をつぎのように整理している.

老年期とは，加踰に伴う精神的肉体的能力の衰 退, 労働市場における商品としての価値の喪失, あるいは家族の周期段階の変化の結果, 職業活動 や親としての役割から引退をし，やがておとずれ る死に対して準備する時期である.

以上のように, 高齢期および高齢者とは,「梷失」 と関連づけられている事が明らかである，老いは 䟔失であると，見做される。いろいろな喪失があ るが，その岥失の始まりは老いの徴候として認知 されるであろう。どの喪失, したがって何が特に 老いの始まりの徴候と見做されるのか.
本稿の目的は, 老いの始まりの徵候の認知に関 し,性差と年齢差についての知見を得る事である。

\section{II 対象と方法}

1. 対象

沖縄県の本島北部の過疎地域, 同中部の新興近 郊都市，同宮古地区の離島漁村地域の老年者，中 年者, 若年者を調査対象とした。ここで，老年者 とは65歳以上の成人, 中年者とは25歳以上65歳未 満の成人, 若年者とは高校生である. 標本は各地 域の, 老年者については同人口の $4 \%$ (448人), 中年者については $1 \%$ （519人）を無作為に抽出し た。回収率は $87.8 \%$ である.若年者については各 地域に所在する高校 2 年生から, 無作為に学級単 位で都市地区は 4 クラス，それ以外は各 2 クラス 抽出した（合計 333 人）。回収率は $100.0 \%$ ある。 欠損値のあるケースを除き，本稿の分析で用いた のは802人である.性・年齢の内訳を表 1 に掲げる.

2. 調查の実施

調査は1990年10月から12月にかけて実施した. 中年者・老年者については質問紙の留置法によっ た。若年者は授業時間内で一斉調査をした。

3. 調查項目

「高齢期における世代関係」を捉えるためにデ モグラフィック関連項目を含む全47設問項目より なるアンケートを用意した。ただし若年用, 中年 用，老年用により設問数には若干の異同がある. このうち, 本稿では各年齢層共通の「老いの始ま りの徴候」に関する設問に限って分析を施す。（調 查の詳細については新垣ら1993を参照されたい).

調査項目の妥当性と信頼性について付言してお $<$.

まず，調查項目の妥当性について述べる，本研 究で採用した老いの始まりの徴候に関する項目

表 1 調査対象内訳

\begin{tabular}{|c|c|c|c|c|}
\hline 年 & 粎令 & 男 性 & 女 性 & 小 計 \\
\hline 若 & 年 & 134 & 180 & 314 \\
\hline 中 & 年 & 141 & 163 & 304 \\
\hline 老 & 年 & 80 & 104 & 184 \\
\hline 小 & 計 & 355 & 447 & 802 \\
\hline
\end{tabular}


表 2 老いの始まりの徴候の認知

問 1 あなたにとって「老人」とは，どういう時を境として始まるとお考えですか， 次の中から 2 つ選んで下さい.

\begin{tabular}{rrr}
\hline \multicolumn{1}{c}{ 老いの徵候項目 } & 実数 & \multicolumn{1}{c}{$\%$} \\
\hline 1) 仕事を止めたり，仕事が思うようにできなくなったとき & 227 & 28.3 \\
2) 年をとって家事がおっくうになったとき & 68 & 8.5 \\
3）年をとって身体の自由がきかなくなったとき & 473 & 59.0 \\
4）もの忘れが多くなったとき & 170 & 21.2 \\
5）配偶者と死別したとき & 15 & 1.9 \\
6) 子供が結婚して独立したとき & 36 & 4.5 \\
7) 孫ができたとき & 96 & 12.0 \\
8）人から「おじいちゃん」「おばあちゃん」と呼ばれたとき & 137 & 17.1 \\
9）ゲートボール等に誘われるようになったとき & 36 & 4.5 \\
10）年金が生活費を支えるようになったとき & 281 & 35.0 \\
11）その他 & 7 & 0.9 \\
\hline
\end{tabular}

は, 内閣総理大臣官房老人対策室 (1982), を参考 に「その他」を含む全11個を設定した（表 2 を参 照の事)。これらの項目は，老年期に生じる喪失, または新しい取得役割を示している。これらの内, 仕事を止める，年金が生活費を支える，の各項目 は，職業からの引退，それに伴う経済的基盤の衰 失要因である。家事おっくう，身体の自由きかな い, もの忘れ多い, は心身機能の衰退, 配偶者と 死別, 子供独立, 孫誕生は, 家族周期段階の変化 の要因である.ゲートボールに誘われる，おじい ちゃんと呼ばれる，は老人に対するステレオタイ プにもとづいた老人像の項目である。

表現方法は異なるものの，これらの項目は，内 閣総理大臣官房広報室（1993）にも引き続き採用 され，調査項目としては一般的であると考えられ る.

なお，本研究で採用した項目には，社会的つな がり, 生きる目的等と関連した老いの始まりの徵 候や内容や人生の統合の意識などの項目は含まれ ていない.その点では老いの始まりの徵候を十全 にカバーしているとは言いがたい.しかしながら， 表 2 に見られるように，「その他」を選択した者の 比率が $1 \%$ 末満であるのは, 消極的ながらここで 用意した項目が老いの始まりの徵候をほぼ押えて いることの証左なのかもしれない.

つぎに，信頼性について述べる．本研究の基と
なった調査は一回切りのものであり,したがって テスト・リテスト法での信頼性の検討はできない. また, 各項目の選択比率を問題にしているので, 通常の検查得点を基にした折半法も適用できな い.そこで，調査対象に一連番号を付し，奇数群 と偶数群に分け，それぞれの群内での各項目ごと の選択比率をもとに正規化標準点を求めた。これ によって両群の偏差積率相関を求め, これをもっ て信頼度係数とした。結果は, $\mathrm{r}=.974(\mathrm{df}=8$, $\mathrm{p}=.000$ )となった。十分信頼性を備えていると見 做せよう。

4. デー夕の処理

データの統計的処理は, まず, 性と年齢を一括 して各老いの徴候項目に対する応答を調べた。つ いで老いの徵候項目ごとに $\chi^{2}$ 検定によって性差, 年齢差を調べた。この時，性と年齢を一括した場 合と，年齢または性の影響を除外した場合のそれ ぞれについて検定を施した。いずれも統計解析ラ イブラリーSAS の FREQ プロシージャーを用い た.

また，老いの徵候の認知の有無を目的変数，性 と年齢を説明変数とするロジステック回帰分析を SAS の CATMOD プロシージャーによって施し た。この方法によって各老いの徴候の認知に対す る性と世代の交互作用の検出を企図した。次に, 林の数量化第III類によって, 老いの徴候項目の分 
類を試みた. 統計分析は富士通の統計解析ライブ ラリーANALYSTを用いた.ついで数量化後の サンプルスコアを基にして, 性, 年齢, および性 と年齢の交互作用，のモデルによる分散分析を施 した.この分析にはSAS の GLM プロシージャー を用いた。演算は九州大学大型計算機センターの 統計解析ライブラリーを利用し, 一部 PC-SAS も 使用した。

本稿では, 地域要因の絡んだ分析は一切施して いない.

\section{III 結 果}

1. 老いの始まりの徵候の認知一全体的傾向 老いの始まりの徴候 (以下, 老いの徴候, と略 記する)として,「その他」を含む11項目を用意し, その中から 2 つ選択させた結果が表 2 に揭げてあ る.それによると,「年をとって身体の自由がきか なくなったとき」が59\%の者に「老いの始まりの
徵候」として認知されている事が示されている. この項目のみが $50 \%$ を越えて選択された。ついで 「年金が生活費を支えるようになったとき」 $35 \%$ ， 「仕事を止めたり，仕事が思うようにできなくなっ たとき」 $28.3 \%$ ，「もの忘れが多くなったとき」 $21.2 \%$ となっている. 以上が選択率 $20 \%$ 以上の項 目である。

2. 老いの始まりの徴候の認知の性差 老いの徴候ごとにその項目の選択率の性差につ いて $\chi^{2}$ 值,一般連関の $\mathrm{CMH}$ 統計量を表 3 に掲げ た. $\chi^{2}$ 検定の結果が有意であることは, 性と老い の徴候項目が連関していること, すなわち性の違 いによって老いの徵候項目の選択率に違いのある 事を意味している.一般連関の $\mathrm{CMH}$ 統計量は, 老いの徴候項目の選択率を若年, 中年, 老年の年 齢によって認整した後の, 性と老いの徵候項目の 連関を示している. なお, 項目「その他」は度数 が小さいので以下の統計的分析から除外した。

\section{表 3 老いの始まり。の徵候に関する認知の性差}

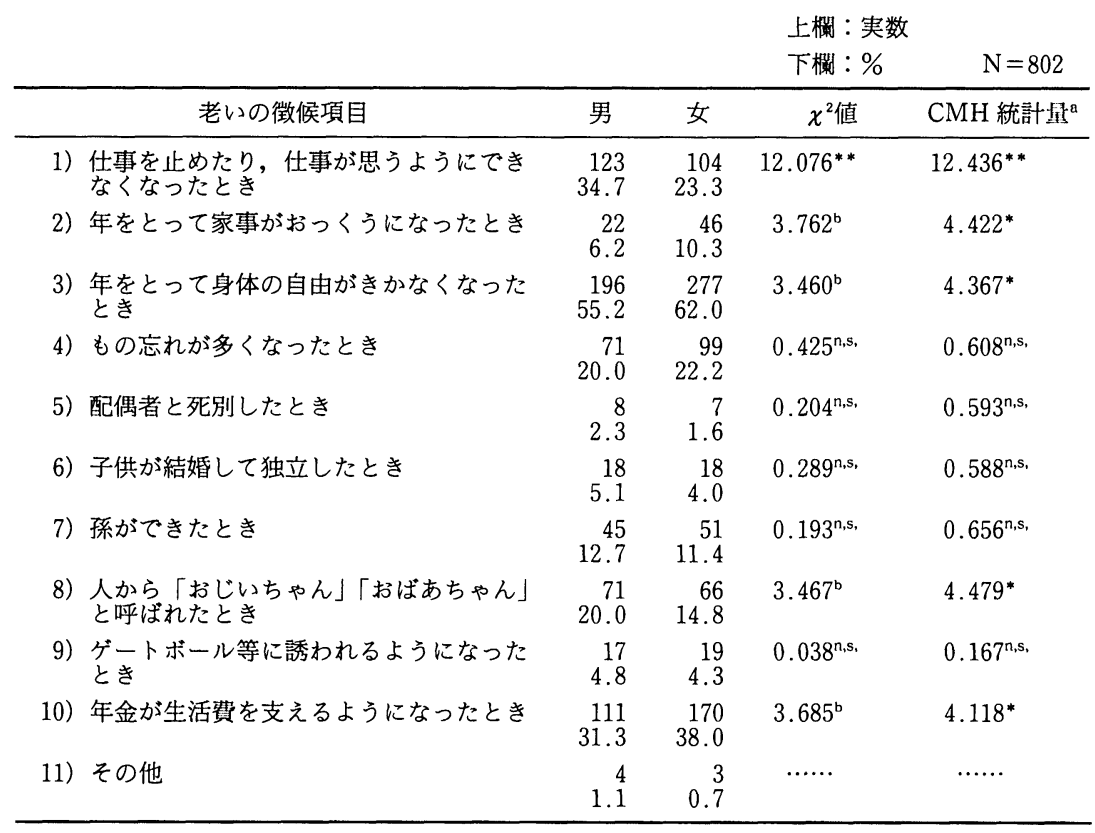

${ }^{a}$ Cochran-Mantel-Haenzel の一般連関の統計量

b. $05<\mathrm{p}<.10$

${ }^{*} p<.05{ }^{* *} p<.01 \quad{ }^{n, s}$.not significant 
表 4 老いの始まりの徴候に関する認知の年齢差

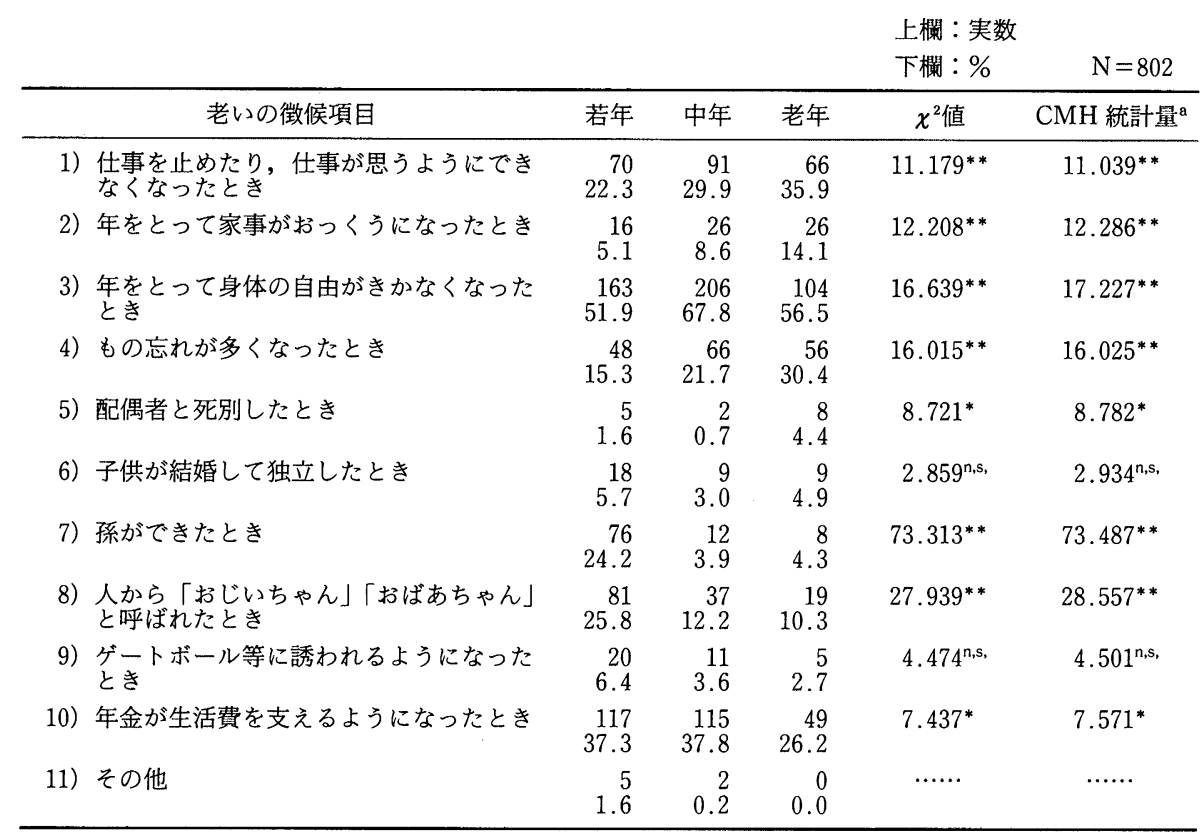

${ }^{\mathrm{a} C}$ Cochran-Mantel-Haenzel の一般連関の統計量

${ }^{*} \mathrm{p}<.05 \quad{ }^{* *} \mathrm{p}<.01 \quad{ }^{\mathrm{n}, \mathrm{s}}$, not significant

有意に男性の選択率が高い老いの徴候は「仕事 を止めたり，仕事が思うようにできなくなった」 と「人からおじいちゃん，おばあちゃんとよばれ るようになったとき」である．有意に女性の選択 率が高いのは「年をとって家事がおっくうになっ たとき」，「年をとって身体の自由がきかなくなっ たとき」，「年金が生活費を支えるようになったと き」である.

3. 老いの始まりの徵候の認知の年齢差

老いの始まりの徵候の認知の年齢差, つまり老 いの徵候と年齢の連関の有意性について, $\chi^{2}$ 検定 と一般連関の $\mathrm{CMH}$ 統計量の結果は一致し, 10 項 目中 8 項目において有意となっている（表 4 参照 のこと). 以下有意となった項目についてその特徵 を列挙する.

世代が上がるにつれて，選択率が漸増する老い の徵候は,「仕事を止めたり，仕事が思うようにで きなくなったとき」,「年をとって家事がおっくう になったとき」,「もの忘れが多くなったとき」の
3 項目である.

世代が上がるにつれて, 選択率が漸減する老い の徵候は，人からおじいちゃんおばあちゃんと呼 ばれるとき」の 1 項目のみである。

若年, 中年, 老年におけるそれぞれの選択率が 逆 $\mathrm{V}$ 型になっているのは,「年とって身体の自由 がきかなくなったとき」と「年金が生活費を支え るようになったとき」の 2 項目である.

また，V 字型になっているのは，「配偶者と死別 したとき」と「孫ができたとき」の 2 項目である.

「子供が結婚して独立したとき」と「ゲートボー ルに誘われるようになったとき」の 2 項目は年齢 との有意な連関がなかった。

4. 性と年齢を説明要因とするロジスティック 回帰分析

最初，次のように性と年齢の交互作用を含むモ デルで分析を行った。

老いの徴候 $=$ 性十年齢 + 性 $\mathrm{x}$ 年齢 その結果, どの老いの徵候項目についても最尤度 
法による適合度の検定では当てはまりが良くな かった.つまり,交互作用を含むモデルはこのデー タの分析には適しないということである.そこで, 交互作用の項を外した次のモデル，すなわち主効 果モデルによる分析を施した。

老いの徵候=性十年齢

最尤度法による検定の結果, このモデルは適合す る事が明らかになった。

各々の老いの徵候項目ごとのロジスティック回 帰分析では，先述の性差の分析および年齢差の分 析結果と同じであった，つまり性の主効果，年齢 の主効果の有意性について表 3 および表 4 に掲げ る結果を確認するものであった（表は省略した）.
5. 老いの徵候項目のパターン分類

老いの徴候10項目の選択・非選択を基に，数量 化第III類によるパターン分類の分析を施した．第 3 解まで求めた（カテゴリーウエイト表は省略し た).

解 1 : この解にプラスの高いカテゴリー・ウエ イトを示す項目は，「孫ができた」「子供の独立」 「配偶者との死別」など，家族周期と関連が深い. マイナスのウエイトでは「身体の自由がきかない」 「もの忘れが多い」など，健康と関連が深い。「家 族周期一健康」軸であろう.

解 2 : プラスの高いカテゴリー・ウエイトを示 す項目は「子供が独立」「配偶者と死別」「家事が

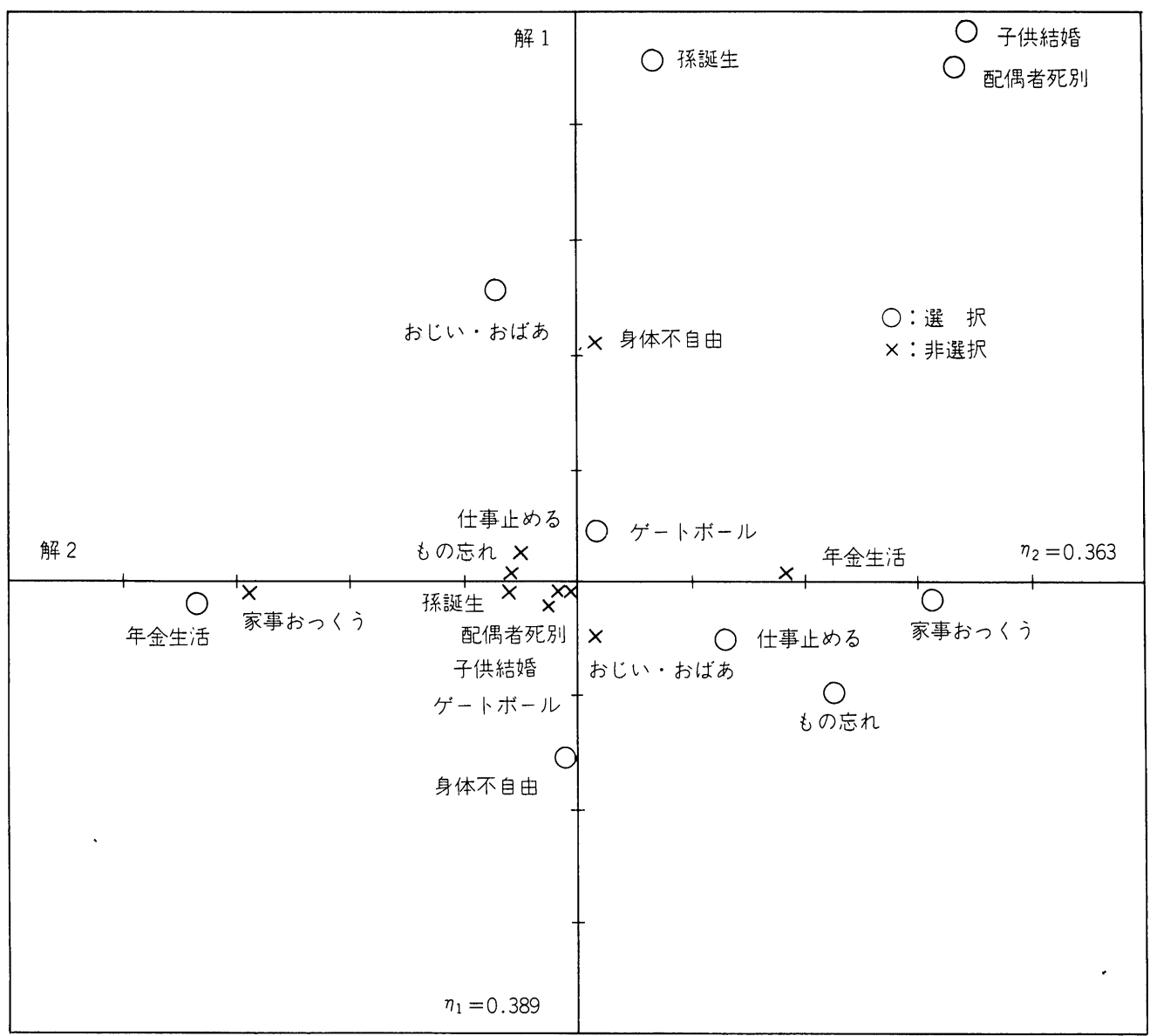

図 1 老いの始まりの徵候項目の布置（解 $1 \times$ 解 2） 


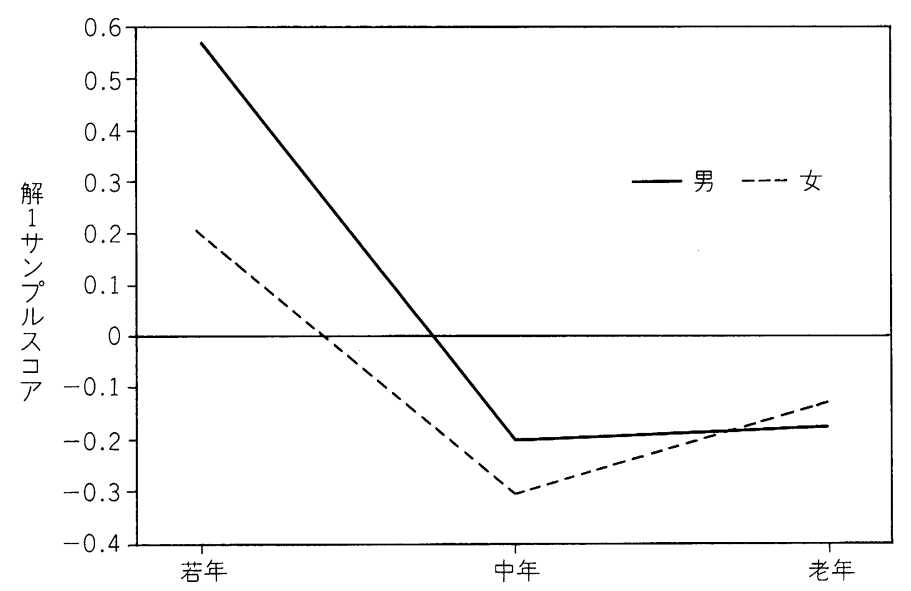

図 2 解 1 サンプルスコアの性別・年齢別平均值

おっくう」などで「孤独」性で特徴づけられる. マイナスの高いカテゴリー・ウエイトを示す項目 は「年金」である。「孤独一年金」の軸であろう。 解 3 : プラスの高いカテゴリー・ウエイトを示 す項目は「もの忘れ」「ゲートボールに誘われる」 などである.マイナスの高いカテゴリー・ウエイ 卜を示す項目は「仕事を止めた」などである。「も の忘れ一引退」の軸であろう.

これら 3 つの解を軸とする 3 次元空間を想定 し，8分割されたそれぞれの空間のいずれかにカ テゴリー・ウエイトでもって老いの徴候項目を位 置づけたところ 8 分割されたそれぞれの空間に布 置したのは各 1 項目程である.これではパターン 分類する意味がほとんどない.そこで, 解 1 と解 2 のカテゴリー・ウエイトを用いて, 老いの徵候 項目の布置を示した(図 1参照). 図によると, 第 1 象限は「配偶者死別」「子供独立」「孫誕生」で 家族周期のパラダイム・シフトと読み取ることが できる、第 2 象限は，「おじいちゃん，またはおゔ あちゃん，とよばれる」いわば他律的な老人性の ラベリングである. 第 3 象限は, 「身体の自由がき かない」の健康要因と,「年金が生活費の支え」の 経済的な要因を表す. 第 4 象限は, 「家事がおっく う」「もの忘れ多い」「仕事を止める」など, 意欲 の減退と関係している.

6. 解 1 のサンプル・スコアの分析
表 5 解 1のサンプルスコアの GLM による分散 分析表

\begin{tabular}{lrcrrc}
\hline 変動因 & 平方和 & 自由度 & 平均平方 & \multicolumn{1}{c}{$\mathrm{F}$} & $\mathrm{P}$ \\
\hline 性 & 3.086 & 1 & 3.086 & 3.39 & 0.0658 \\
年齢 & 72.182 & 2 & 36.091 & 39.69 & 0.0001 \\
性 ${ }^{*}$ 年齢 & 6.265 & 2 & 3.132 & 3.44 & 0.0320 \\
残差 & 723.891 & 796 & 0.969 & & \\
\hline
\end{tabular}

解 1 のサンプル・スコアを従属変数とする GLM の結果を表 5 に掲げた。解 1 は「家族周期 一健康」の軸である.

年齢の主効果と, 性と年齢の交互作用が有意と なっている. 性の主効果は有意でない. 年齢別, 性別にサンプルスコアの平均值を図 2 に掲げた。

年齢差について概観すると，若年群の場合は家族 周期的な側面で老いの徵候を認め，中年以降は健 康的側面で老いの徵候を認知している.

年齢群ごとに男女間の比較を行うと, 若年群で は男性が女性より家族周期要因で老いの認知を し, 性差は有意である.中年群と老年群では性差 は有意でない。次に，性別に年齢群間比較を行う. 男性においては，若年と中年，若年と老年間には 有意差があり，中年と老年間には有意差がない。 女性においても，若年と中年，若年と老年の間に は有意差があるが, 中年と老年の間には有意差が 認められない(多重比較の表は省略した)，以上を 


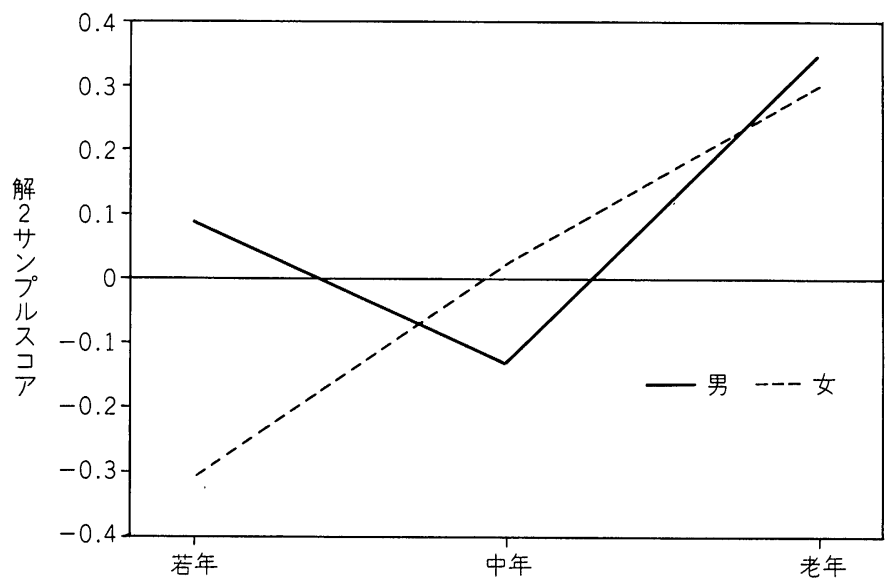

図 3 解 2 サンプルスコアの性別・年齢別平均值

表 6 解 2 のサンプルスコアの GLM による分散 分析表

\begin{tabular}{lrrrrc}
\hline \multicolumn{1}{c}{ 変動因 } & 平方和 & 自由度 & 平均平方 & \multicolumn{1}{c}{$\mathrm{F}$} & $\mathrm{P}$ \\
\hline 性 & 1.681 & 1 & 1.681 & 1.75 & 0.1858 \\
年齢 & 23.583 & 2 & 36.091 & 39.69 & 0.0001 \\
性 * 年齢 & 11.645 & 2 & 3.132 & 3.44 & 0.0024 \\
残差 & 763.103 & 796 & 0.969 & & \\
\hline
\end{tabular}

まとめると, 若年群は老いの徴候を家族周期の側 面で捉え，かつその傾向は男性において顕著であ る. 中年以降では男女とも老いの徴候を健康の側 面で捉えているという結果である.

7. 解 2 のサンプル・スコアの分析

解 2 のサンプルスコアを従属変数とする GLM の結果を表 6 に掲げた。解 2 は「孤独一年金」の 軸である。

年齢の主効果と, 性と年齢の交互作用が有意で あり, 性の主効果は有意となっていない。年齢群 別, 性別にサンプルスコアの平均值を図 3 に掲げ た

年齢群ごとに男女間比較すると, 若年群では男 性は孤独を女性は年金を老いの徴候として認知 し，その性差は有意である. 中年および老年群で は性差は有意でない, 次に, 性別に年齢群間の比 較を行う. 男性の場合, 若年と中年, 若年と老年 の間には有意差はなく, 中年群と老年群間に有意
差が認められた。中年群は年金の方向に, 老年群 は孤独の方向に老いの徴候を認めている，女性の 場合は年齢が進むにつれて，年金から孤独の方へ ほほ直線的に変化している。そして全ての年齢間 で有意差が認められる（多重比較表は省略した）。 なお, 解 3 のサンプルスコアを従属変数とする GLM の結果, 性の主効果のみが有意となり ( F = $6.85, \mathrm{p}<0.009)$, 年歯の主効果および性と年跲の 交互作用は有意でなかった(分析表は省略)。男性 は引退，女性はもの忘れとして老いの徴候を認め る方向にある。

\section{IV 考察}

老いの始まりの徵候項目として用意された11個

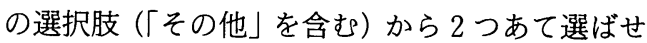
て，老いの始まりの徴候の認知の性差，年齢差を 捉えようと試みた。分析に使用したサンプル数は 802人である。

全デー夕を一括すると,老いの始まりの徴候は, まず「年をとって身体の自由がきかなくなったと き」(59\%)として認知されている，身体機能の低 下による老いの始まりの徵候である．古谷野ら （1993）は，「健康は老人の生活の態様を規定し， 幸福な老い (Successful aging) の可否を決定する 最大の要因である」と述べ，高齢者の生活機能の 自立性について報告している.予想されるように, 
加齢に伴って活動能力は低下していた．ADL（日 常生活動作能力) 研究によると, 加齢に伴い ADL が低下すること, ADL の低下と生命予後には強い 関連があることが報告されている（橋本ら1986, 藤田1989, 藤田・波多野1990, など). しかし, ADL が向上する例のある事も報告されている（安田ら 1989).この項目を老いの始まりの徴候と認知する のは女性において敏感である(オッズ比は1.355).

ある一定年齢を過ぎると, 加齢に伴って身体の 自由がきかない事態は漸増するもののように考え られる.しかし，年齢間比較によると比率の高さ は, 若・中・老の年歯群間で逆 $\mathrm{V}$ 字型を示してい る.つまり，身体の自由がきかないことで老いの 始まりを認知するのは, 老年群ではなくて中年群 である. 中年群の年齢区分を, 中年初期（25～34 歳), 中期 ( $35 \sim 49$ 歳), 後期 ( $50 \sim 64$ 歳) と整理 し直して $\chi^{2}$ 検定したところ, 年齿間の変動は有意 でなかった $\left(\chi^{2}=0.201, \mathrm{df}=2, \mathrm{p}<0.904\right)$.すな わち, どの年齢段階にあろうが高い比率で選択さ れ, 年齢間差がない.ということは, すでに 20 代 から, 身体の自由のきかないことを, 老いの始ま りの徵候として認知し始めていることが窅える. また，老年群についてもさらに細かく年齢区分し て年齢間差を調べたが，この場合も有意でなく， 老年群のどの年齢でもほぼ同様の選択率である.

ついで，選択率の高い項目は「年金が生活費を 支えるようになったとき」(35\%)である，経済的 基盤の変化すなわち収入源の年金への転換が挙げ られている。ただし，年金の問題は経済的な側面 を持つのは言を俟たないが，一方，いわば年金の 受給年齢として暦年齢に基づく法制度上の社会的 老齢規定的な側面も見落としてはならないだろ う。年金が生活費を支えるとは，年金生活者にな ることである.つまり, 職業生活から引退し, 隠 居になることであろう。そのような機会に遭遇す るのは男性に多いはずである，しかし，年金受給 で老いの始まりの徴候と考えるのは女性に多い. この結果は「高齢期の生活イメージに関する世論 調査」(内閣総理大臣官房広報室, 1993) とも一致 している.女性は老齢年金受給年齢に達する事で
老いを制度的に公認され, 年金生活者の地位を獲 得することになる，老いの公認がすなわち老いの 始まりの徵候を表すということである. 年齢で見 ると，年金が老いの始まりの徴候と認知する者の 比率は, 若年群と中年群でほほ同じで, 老年群よ り高い.いわば法制度上の区分によって老いの始 まりが決定され，その決定を追認するのが若年・ 中年群であり, 年金受給当事者である老年群には あまり受け入れられていない. 老年群には, 年金 よりも主要な老いの始まりの徴候と思わしめる事 柄がある，ということであろう。

「仕事を止めたり，仕事が思うようにできなく なったとき」(28.3\%)というのは, 職業からの引 退ないし心身機能の低下による仕事の継続の困難 さを示している.いずれにしても生産性からの撤 退である。そして，それに伴う経済的基盤の喪失 も意味する．これを老いの始まりの徵候とするの は男性に多い（オッズ比は1.794）。一般的に, 男 性は就職し経済的基盤を作ることが期待され, や がて職業から引退する.したがって, この性差の 存在については妥当な結果であろう。また，年齢 が高くなるにつれて，この項目を老いの始まりの 徵候と認知する比率が漸増するのは，しだいに， この事実が個別的・具体的に把握されるようにな ることを意味するのであろう.

このように, 健康の喪失, 経済的基盤の喪失, あるいは退職が老いの始まりのドミナントな徵候 として認知されている.これらに対して, 家族周 期段階の変化に関連した項目については老いの始 まりの徴候として認知される度合いは低い。この 結果は「老後の生活についてのイメージ」調査の 結果と軌を一にしているようである。すなわち老 後とは, 日本人の場合「健康が衰えた後の生活」 「年金生活者としての生活」,「仕事から引退した生 活」としてイメージされている（内閣総理大臣官 房老人対策室, 1982).ただし，このイメージは60 歳以上の高齢者に扔けるものであり, 若年, 中年 は含まれていない。

山下（1973）は「老人という問題意識は，単に 暦の上の年龄からではなくて，身体的・精神的な 
衰えに起因するものである，就労の困難さも，家 庭や社会への不適応も，そこに端を発している. 老人問題の中で保健の役割の重く大きいことを主 張するゆえんである」と述べている。本稿との関 連で言えば，身体的・精神的衰えには「身体の自 由がきかない」「もの忘れが多い」の 2 項目が含ま れる事になろう。すなわち，心身の機能の衰退に より，「仕事が思うようにできなくなった」り，「家 事がおっくう」になったのである，と解釈できよ う. 本研究では, しかしながら保健行動や, 健康 維持増進活動に関する項目を調査していないの で，より深い分析は残されたままである。

2. 老いの徵候の類型と性・年齢の関連

図 1 に老いの始まりの徵候項目のパターン分類 の結果を示した。第 $1 \sim 4$ 象限を老いの始まりの 徵候類型と見做して，それぞれの象限の解釈を試 みる。

第 1 象限は, 子供の結婚, 孫の誕生, 配偶者と 死別の徵候に代表される家族周期の段階の移行で
特徵づけられる.「家族周期の変化」型と呼ほう(以 下，家族周期，と略記する)。

第 2 象限は，おじいちゃんまたはおばあちゃん と呼ばれるというものであり,「老人標識」型と解 釈できる。

第 3 象限は，横軸（解 2 ）に対して「年金が生 活費を支える」と縦軸（解 1) に対して「年をとっ て身体が自由に動かない」という健康喪失の $2 つ$ の徵候で特徵づけられる.「健康品失と年金」型で ある（以下，健康喪失，と略記する)

第 4 象限は「家事がおっくう」「もの忘れが多い」 「仕事を止めたり，仕事が思うょうにできない」と いった「意欲喪失」型，と解釈される。

老いの始まりの徵候の類型と性, 年龄の関連を 見るためにサンプルスコアの平均值によって性 別・年齢群別の布置を図 4 に示した。男性は年齢 群別に見ると若年群は「家族周期」型，中年群は 「健康喪失」型, 老年群は「意欲品失」型に布置し ている．女性の若年群は「老人標識」型，中年群

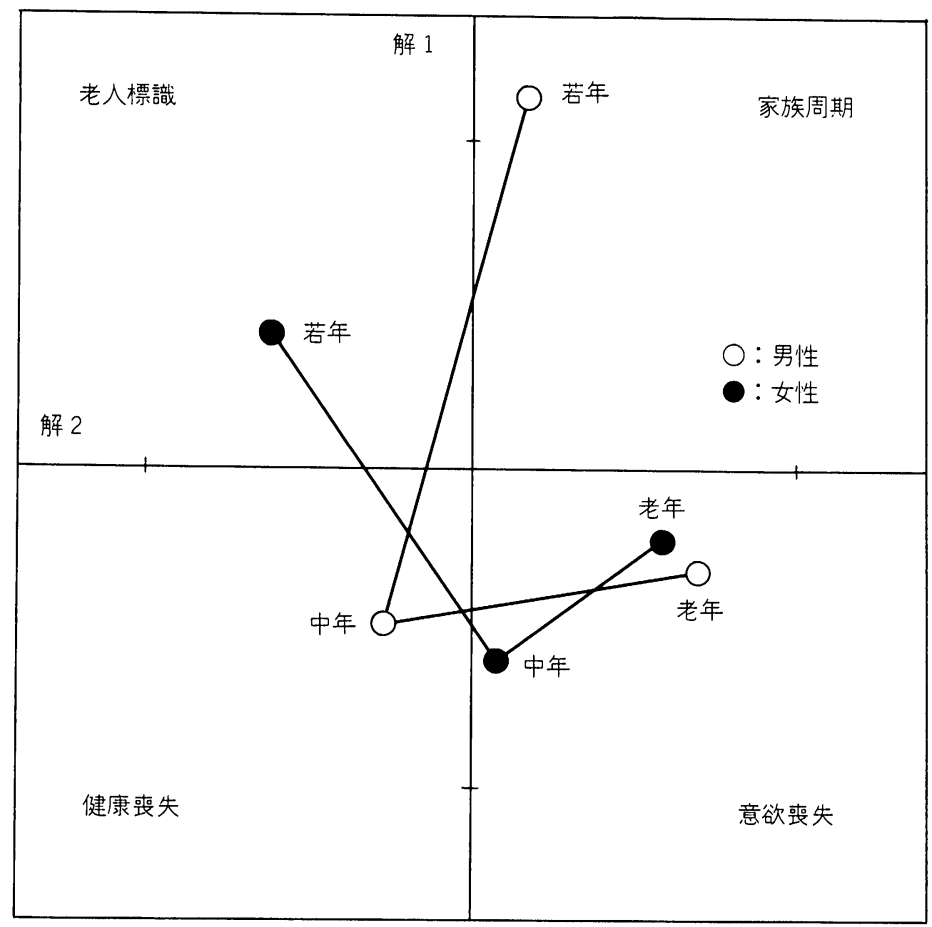

図4＼cjkstart老いの始まりの徵候の類型と性・年柃 
表 7 老いの始まりの徴候類型の人数内訳

\begin{tabular}{lcrrrrr}
\hline 徵候類型 & 若年 & 中年 & 老年 & 男性 & 女性 & 合計 \\
\hline 家族周期 & 89 & 31 & 43 & 87 & 76 & 163 \\
老人標識 & 66 & 65 & 26 & 61 & 96 & 157 \\
健康喪失 & 66 & 137 & 89 & 127 & 165 & 292 \\
意欲品失 & 93 & 71 & 26 & 80 & 110 & 190 \\
\hline
\end{tabular}

は「意欲喪失」型と「健康吘失」型の境界, 老年 群は「意欲品失」型に布置している. 老年群では 性差はなく，男女共に「意欲袈失」を老いの始ま りの徵候と見做している.

老いの始まりの各類型の, 年齢群別, 性別の人 数の内訳を表 7 に揭げた.「健康㹾失」型に属する 者がもっとも多く,「老人標識」型に属する者が もっとも少ない， $\chi^{2}$ 検定の結果は有意である $\left(\chi^{2}=58.708, \mathrm{df}=3, \mathrm{p}<.001\right)$. 身体の衰元, 年 金の受給が老いの始まりの徵候として認知される ことが多い. 生物学的老化要因, 社会的要因が両 様に老いの始まりの徵候として同時に把握されて いる事が示唆される。

性と類型については, 連関の傾向が認められる $\left(\chi^{2}=7.776, \mathrm{df}=3, \mathrm{p}=.051\right)$. 男女とも「健康喪 失」型がドミナントである.

年齢と型の連関を検討すると，これは有意であ る $\left(\chi^{2}=74.453, \mathrm{df}=6, \mathrm{p}<.001\right)$. 若年群は「意 欲品失」型と「家族周期」型, 中年群と老年群は 「健康喪失」型が多い. 全般的には中年群の「健康 竦失」型がもっとも多く，そろそろ老いを知覚し 始め, 身体的徴候としては体力の衰元, 経済的次 元としては経済的自立の衰失, 他者への依存を余 儀なくされる「老いの受容」の備えが必要とされ る時期であろう。老年群での「老人標識」型と「意 欲培失」型がもっとも少ない.このように老いの 始まりの徴候の認知には年齢間差がある.

本稿は,「老いは喪失である」との視点から老い の始まりの徴候の認知を検討した．しかしながら 「老年期は，衰退期とも円熟期ともいわれてきた が，これまでの老年期に関する心理学的研究は主 に衰退的変化を実証することにむけられてきたき らいがあった」(下仲，1994）とする主張もある.
本研究は円熟の側面からの老いの始まりの認知を 検討していない.この点については, 残された課 題である.

\section{V 結 論}

何をもって,老いの始まりの徵候と見做すのか, 若年・中年, 老年者の男女 802 人について，その性 差，年齢間差を中心に検討した。

1）老いの始まりの徴候として，「年をとって身 体の自由がきかなくなった」を老いの始まりとす る者が59\%で最も多い，ついで「年金が生活費を 支える」(35\%)，「仕事を止めたり，仕事が思うよ うにできなくなった」(28\%) となっている.

2）男性は女性より「仕事を止めたり，仕事が思 うようにできない」ことで老いの始まりの徴候と する率が高い。

3）女性は男性より「年をとって身体の自由がき かなくなった」，「年金が生活費を支える」ことで 老いの始まりの徴候とする率が高い.

4）「年をとって身体の自由がきかなくなった」 とする老いの始まりの徴候項目は年齢と有意な連 関があり, 若年者, 中年者, 老年者の選択比率は それぞれ $52 \% ， 68 \% ， 57 \%$ ある。

5）「仕事を止めたり，仕事が思うようにできな い」とする老いの始まりの徴候は, 年齢があがる にしたがってその選択比率が漸増する。

6）「年金が生活費を支える」とする老いの始ま りの徵候認知は，若い世代ほど高い.

7）若い世代ほど「ひとから，おじいちゃん，お ばあちゃん，と呼ばれる」ことで老いの始まりの 徵候とする比率が高い.

8）数量化第III類によって,老いの始まりの徵候 10 項目は「健康賈失と年金」「意欲䟔失」「家族周 期の変化」「老人標識」とパターン分類された.

9）「健康品失と年金」を老いの始まりの徵候と するものがもっとも多く，「老人標識」を老いの始 まりの徵候とするものはもっとも少ない.

10）男性の若年者は「家族周期の変化」要因, 中年者は「健康喪失と年金」要因，老年者は「意 欲虽失」要因を老いの始まりの徴候としている. 
11）女性の若年者は「老人標識」要因，中年者・ 老年者は「意欲岥失」要因を老いの始まりの徴候 としている。

〔附記〕

1. 本研究のデータは, 平成 $2 \sim 3$ 年度科学研究費補 助金 (研究代表者・新垣都代子, 琉球大学教育学部教 授）によるプロジェクトで得られたものです．調査に ご協力下さいました皆様にお礼申しあげます。

2. 本研究をまとめるにあたり, 豊川裕之先生 (東邦 大学医学部教授）にご指導を賜りました。ここに記し て媣甚の謝意を表します。

\section{文献}

藍澤鎮雄, 田久保栄治, 中沢治彦, 他 (1991) : 老年 期と不安感, 臨床精神医学, 20(1)，13-20

アンダーソン, S. 他(重松逸造, 柳川 洋, 監訳) 1982, 疫学・臨床医学における比較研究の統計学, ソフト サイエンス社 (東京) Anderson, S. \& Others (1980) : Statistic a Methods for Comparative Studies. John Wiley \& Sons Inc.

荒井保夫 (1988)：高齢者の心の健康, 老年社会科学, $10(2), 139-158$

藤田利治（1989）：地域老人の日常生活動作能力低下 の生命予後への影響, 日本公衛誌, 36(10), 717-729

藤田利治, 籏野脩一（1990）：地域老人の生命予後関 連要因についての 3 地域追跡研究, 日本公衛誌, $37(1), 1-8$

芳賀 博, 柴田 博, 上野満雄, 他 (1991)：地域老 人における健康自己評価からみた生命予後，日本公 衛誌，38(10)，783-789

長谷川和夫, 賀集竹子, 編著 (1977)：老人心理への アプローチ，医学書院（東京）

橋本修二, 岡本和士, 前田 清, 他 (1986)：地域高 萪命者の生命予後に影響する日常生活上の諸因子につ いての検討，日本公衛誌，33(12)，741-747

井上勝也(1988)：老年期と生きがい, 老年社会科学, $10(2), 243-254$

厚生統計協会 (1992): 国民衛生の動向（厚生の指標, 臨時増刊, 39(9))

古谷野亘, 橋本廸生, 拊川哲夫, 柴田 博, 郡司篤晃 （1993）：地域老人の生活機能, 日本公衛誌, 40(6), 468-473

松崎俊久 (1984)：戦後日本人の寿命の伸びとその背 景, 松崎俊久 編著, 寿命, 7-46, 女子栄養大学出版 部 (東京)

守屋国光, 長谷川恒雄 (1979)：心身機能の連関性か らみた老年期の衰退過程, , 社会老年学, 10，63-78
内閣総理大臣官房老人対策室, 編 (1982)：老人の生 活と意識, 大蔵省印刷局（東京）

内閣総理大臣官房広報室, 編 (1993) : 高齢期の生活 イメージに関する世論調査, 大蔵省印刷局（東京）

新垣都代子, 玉城隆雄, 大城冝武, 花城梨枝子 (1993) 沖縄の高萪命者をめぐる世代関係, 多賀出版（東京）

小川 裕, 岩崎 清, 安村誠司 (1993)：地域高齢者 の健康評価に関する追跡的研究, 日本公衛誌, 40 (9), 859-871

沖縄県環境保健部 (1992)：平成 2 年衛生統計年報 (人 口動態編)，沖縄県

沖縄県企画開発部（1992）：沖縄県の人口（平成 2 年 国勢調查)，沖縄県

ピット，B．木戸又三，訳(1977)：精神老年医学入門， 文光堂，(東京) Pitt, B. (1974)：Psychogeriatrics, An Introduction to the Psychiatry of Old Age, Churchill Livingstone, (Edinburgh)

SAS User's Guide (1990): Statistics. Version 5 Edition. SAS ソフトウェア株式会社（東京）

柴田 博 (1993)：人口高齢化の論理, 柴田 博, 芳 賀 博, 長田久雄, 古谷野亘 (編著), 老年学入門, 11-20, 川島書店（東京）

柴田 博, 古谷野亘, 芳賀 博 (1983)：ADL 研究の 最近の動向, 社会老年学, $21,70-83$

清水 信 (1984): 老人の心理生活, 老年精神医学, $1(1), 54-62$

下方浩史 (1991)：老化の指標, 国際長寿科学シンポ ジウム実行委員会事務局 (編) '90国際長寿科学シン ポジウム, 362-367, (名古屋)

下仲順子（1994）：老年期は衰退の時期か, 日本心理 学会58回大会発表論文集, S59

新福尚武 (1994）：Successful Aging，心身医, 34(1), 20-26

袖井孝子（1975）：老年期の社会学的規定，社会老年 学, $2,43-53$

高橋久美子（1989）：老年期における配偶喪失，日本 家政学会誌, 40(7)，575-585

田中平三，政田喜代子，馬場昭美，他（1981）：老人 の社会的適応に関する精神衛生学的研究, 日本公衛 誌，28(2)，59-68

内山道明，吉村智恵子（1991）：高跲者の心理特性, 祖父江逸郎(編), 高齢者の生活と長寿科学, 136-143, 長寿科学振興財団（東京）

Ward, R.A. (1977) : The impact of subjective age and stigma on older persons. Journal of Gerontology, 32(2), 227-232

World Health Organization (1984): The use of epidemiology in the study of the elderly. (WHO Technical Report Series 706) 
山下 章(1973)：老人保健, 日本公衛誌, 20(6), 293 $-297$

安田誠史, 三野善央, 久繁哲徳, 大原啓志, 豊田 誠, 大平昌彦（1989）：地域在宅高齢者の日常生活動作
能力の低下に関連する生活様式, 日本公衛誌, 36(9), 675-681

依田 浩 (1985)：四訂生活の統計学, 光生館 (東京) (受稿 至急 1994.9.21；受理 1994.12.9） 